\title{
Examining the Factors Influencing the Use of Mother Tongue in Iranian EFL Context: A Mixed-Methods Approach
}

\author{
Fatemeh Behjat $^{1}$, Mehdi Dastpak ${ }^{2}$, Ali Taghinezhad ${ }^{3 *}$ \\ ${ }^{I}$ Department of English, Abadeh Branch, Islamic Azad University, Abadeh, Iran \\ ${ }^{2}$ Department of English Language, Jahrom University of Medical Sciences, Jahrom, Iran \\ ${ }^{3}$ Department of English Language, Fasa University of Medical Sciences, Fasa, Iran
}

*Corresponding Author: Ali Taghinezhad, Department of English Language, Fasa University of Medical Sciences, Fasa, Iran

\begin{abstract}
Using first language in EFL classrooms has been a matter of controversy over the years. Language learners make use of their mother tongue consciously or unconsciously when learning a language. In Iranian EFL classrooms, teachers sometimes use first language to make learning more dynamic and to give their students a feeling of security. Several factors influence the use of first language in EFL classrooms. This study aimed at examining those factors along with teachers' perceptions toward the use of first language in teaching. To this end, the researchers followed a mixed-methods approach using open-ended and closedended questions, interviews, classroom observations, and focus group discussion. The results showed that, students found using L1 in the classroom useful. They believed that it is time-saving, effective, anxietyreducing, and motivating. Moreover, the use of L1 can scaffold the students who cannot accomplish the tasks on their own. Some students, however, had opposing views toward using L1 in the classrooms.
\end{abstract}

Keywords: EFL Classrooms, Mixed-Methods Approach, Mother Tongue, Students' Perception

\section{INTRODUCTION}

A controversial issue over the years has been whether to use first language in the EFL classrooms. In Iran, most language teachers at schools use English as much as possible. For a long time, the use of L1 in any EFL classroom was considered an unreasonable misconduct. At the secondary school level in Iran, students habitually use their English language in English classes. Almost all language teachers have experienced such a thing. Sometimes teachers in English secondary schools use L1 in class. Some researchers state that only first language should be used in the classroom. Why EFL teachers use L1 in class seems to be harmless and effective for teaching. Meyer (2008) included reasons for using L1 in the classroom and encouraged "students' L1 to help the classroom become more understandable and help to reduce effective filters when used" (p.148). "Managers of English School should realize that using Target Language (TL) in class is not as effective as you think. Beginner to advanced students should feel comfortable because the new language should not be seen as a vague and terrible field. As an example, language teachers should draw a common structure between languages to understand the structure of a foreign language or a second language.

On the other hand, many teachers and researchers disagree on this issue, arguing that extreme use of L1 may hinder the foreign language learning process. As an English student, as a teacher, many of them have an attitude of sticking to their native language in the classroom. When working as a teacher, the researchers found many students and some Persian teachers albeit in English classes. I asked them the reason behind this achievement, and many times I replied: "This is my native language; I am not a native speaker of English." I was annoyed to find that even if they were learning English, they would use the first Language. It considers for us why they speak their first language while learning English. In this article, the researchers explored the reasons for using L1 in the Iranian EFL classroom where this language is spoken.

There are many arguments in favor of using L1 and against using it in EFL classrooms, but not many researchers use L1 in class to measure the exact effect of L1. Some researchers believe that L1 can be used as a facilitator in the L2 or EFL classroom to develop the teaching process because they think 
teachers have a responsibility to create a comfortable environment for students to express themselves. In contrast, some recent researchers believe that teachers can occasionally use L1 as a useful tool for effective learning. The main purpose of this study was to find out why teachers use Persian in English classrooms in Iran.

\subsection{Foreign Language Teaching in Iran}

There is a increasing awareness of learning English as a second language / foreign language all over the world. English plays a significant role in all aspects of today's life, from education to business. In addition, English has become a global language of communication and a means of global international exchange (Brutt-Griffler 1998). It has recognized people from different cultures and backgrounds in different languages who share their knowledge and skills. In addition, English has become an "integral part of education strategies in most countries" (Graddol 2006, p. 70). Today in Iran, English is used as a foreign language in our classrooms. English is a required course in the national curriculum from the 7th up to the 12th grade. Non-governmental organizations such as language centers, English secondary schools and private universities teach English according to their curricula and syllabuses.

The main goal of English teaching in Iranian high schools is to strengthen the basic knowledge of English so that students can understand simple English commands, instructions and requirements and implement them. Therefore, the correct learning of English at the secondary level is of crucial importance to students. This is why in Iran, most teachers use the Persian language in English classes to explain the meaning of English words or give examples when teaching grammar. In addition to using L1, they cannot actually find any other way to teach English. This is why most English classroom teachers use mother tongue without knowing the rationale behind it. Making English learning effective from primary to secondary schools requires a great deal of input and resources, such as trained teachers, having access to appropriate teaching strategies, communicative resources and management facilities. Unfortunately, however, these resources are not available for learning English in all educational institutions throughout the country.

\subsection{Language Teaching Methods}

Language teaching is usually viewed in terms of approach. To improve teaching practice, teachers and researchers try to find out which method works best. Some methods are used to encourage the use of first language in the classroom, others are not. The first method of teaching English is to encourage grammatical translation using the first language (L1). Lasren-Freeman (1986) pointed out in Grammar Translation Method (GTM), vocabulary and text taught in class is quickly translated into the first language. Grammar is taught in a deductive way, which means that teachers are accustomed to giving grammatical rules and examples and asking students to memorize these rules with examples. Students and teachers communicate almost completely in L1. The instructions are also given in the first language. The success of students depends on their ability to translate from English to their L1. However, in many countries, teachers still use this method to teach English. The teacher always uses Persian to illustrate. Teachers do not encourage class participation or discussion at all. The class is entirely teacher-centered and the teacher is the class's authority, so the students must do what the teacher says and the interaction between the teacher and the student is primarily at its minimum. Teachers encourage the use of first language (L1) in the classroom. In other words, this approach has had almost no effect on improving students' ability to communicate in the language (Brown, 2000, p. 16).

Together with the "Grammar Translation Method" in teaching English in many countries, there are other methods as well. Some of these methods almost prohibit the use of the first language.

Direct Method is one of the methods in which students are not allowed to use their first language. In this method, students use the realia or picture of different objects and the direct connection between the language and its meaning. The first language is not needed in class. Instead of translating and teaching TL thinking, teachers use examples to answer students' questions. In the Direct Method, grammar is taught inductively to teach examples of what was first presented, and the students are asked to find grammar rules from the examples. 
Other methods, such as Audio-lingual, Community Language Learning and Silent Way, do not encourage the use of the first language but allow the use of the first language whenever it is needed. These methods encourage learners to be "autonomous." The role of a student is crucial to learning a new language. These methods encourage self-correction, and if the student cannot do that, the teacher provides support. If necessary, the teacher gives the TL word literal equivalents. This makes the meaning of these words clear, and allows learners to combine TL words in different ways to create new sentences. In this approach, teachers provide a safe environment that encourages student initiative and independence.

Finally, teaching English as a foreign language spread in the late 1970s and early 20th century.

In the 1980s, the use of L1 was considered undesirable based on the communicative approach (Mahmoud, 2006). This trend is supported by the theory of cognitive psychology, where people learn a foreign language in a manner similar to learning L1. In fact, many language teachers are still hesitant to use L1 in L2 / FL classrooms because they think it limits their exposure to TL and allows students to think in their first language. Each method is unique and its own advantages, but not suitable for all situations. One method can be successful if the teacher can use it in the proper way.

Nowadays, the taboo of prohibiting the use of L1 in class is breaking down, as is the attitude of using L1 in English classes. Much of the emphasis now is on communication, not just learning a single language. In fact, a new teaching method deliberately uses L1 in an EFL classroom. This is the New Concurrent Method where teachers have to balance L1 and FL (Faltis, 1990). Here, talking about L1 can be used in four areas: introducing concepts, reviewing previous lessons, capturing learner's attention, and praising them. In addition, as research continues, it has been found that in addition to negative language transfer, positive transfer also seems to be significant, meaning that FL / L2 learners may benefit from similarities in the two languages.

The purpose of this mixed-methods study is to find out how teachers use L1 in a secondary school classroom in Iran. This article investigates teachers' actual use of L1 and why it is used. The role of first language in language teaching has always been controversial. Regarding teachers' use of their mother tongue, teachers think that first language should be used with caution in order to gain more English teaching benefits rather than be overlooked. In the language teaching method, teachers regard the use of learner MT in foreign language teaching as a natural phenomenon. Teachers and educators, whether they like it or not, know that language learners are involved in their language learning and unconsciously use their own language. In language classes, teachers are inspired to use learners' MTs to make them more energetic and help learners feel safe. This article discusses the reasons for using L1 which help teachers modify classroom language to reduce the frequency of first-language use as an essential tool. These studies select secondary classrooms to explore under what conditions teachers use first language in EFL classrooms. To this end, 16 teachers and 70 students were selected to take part in interviews and complete questionnaires and analyze their experience and situation of using first language in foreign language classes.

\section{LITERATURE REVIEW}

There has been controversy over whether to use a teacher's MT in a foreign language class. Using L1 effectively in the classroom can be regarded as a language learning and language teaching tool. Many teachers in EFL classrooms use the first language without knowing the reason for using it. They do not even know L1 can be a means of teaching a second language or a foreign language. Although the use of L1 may hamper second language or foreign language learning, it may also include several advantages.

Language learning and teaching is a continuous process. The level, age and background of language and learners should be taught with a focus on teacher perception. Krashen (1985) claimed in his theory that if a TL is used in a learning environment then a foreign language or a second language is achievable and the use of L1 is given in second language learning and teaching a lot of consideration. If L1 is used effectively, it will promote language learning.

Cangarajah (1999) commented in his book entitled Resisting Linguistic Imperialism in English Teaching on the use of L1 in secondary schools in EFL classrooms. The author illustrates L1 (mother tongue) used in the second language / foreign language classroom in teaching process, classroom 
content and student interaction. He completed "accommodation of L1 in English classroom does not hamper the acquisition of L2, but enhance it" (p. 143). Cangarajah offers examples from Tamil courses: L1 is detrimental to L2, meaning that local teachers are under the influence of central teaching ideas. He believes that teachers and students can effectively manage classroom interactions by using LI, code-switching, and code alternation.

Teachers often use L1 in primary and secondary classes to guide and interpret difficult-to-understand meanings and interpret complex ideas and grammar points (Tang, 2002). The use of in the classroom means "supportive and facilitating role" (Tang, 2002) rather than being the primary language for communication. Using L1 in class allows students to better understand the similarities and differences between cultures and language structures and to improve the accuracy of translation. In order to find similarities between the two languages, the interrelationship between L1 and L2 knowledge is established in the minds of students (Cook, 2001).Using L1 in class may not be perfect. Students can use it if they feel they need it; however, there should be a balance between the two languages. Teachers should not use L1 to protect themselves because they are not prepared for the class. The teacher should know the proper use of his / her native language.

According to Cole (1998), teachers can use L1 when it is really needed and helpful. Teachers can create a safe and motivating environment for language learners. Teachers should use English whenever possible and use English if necessary (Atkinson 1987). Teachers should remember that students should not overly rely on L1.

In some cases, students can use L1. Therefore, the reason teachers can actively teach a second language or a foreign language in a first language is different. Basically, using L1 can save a lot of time and confusion. Before using MT for primary and secondary students in EFL classrooms, teachers may consider using their native language as a tool for signs, images, videos, and more. It can be effective for L2 / FL learning as a constructive resource. L1 can be used as a tool in L2 classroom to reduce affective filters (Meyer, 2008; Norman, 2008). Norman (2008) states that students are often unresponsive, unwilling, and reluctant to speak in class.

Although MT is not a proper basis for a methodology, it plays a variety of roles at all levels and is currently undervalued (Atkinson 1987). According to Atkinson (1987), translation can still be used when the teacher examines the students' understanding. He prefers to use translation as a term for "language expression and reinforcement," and he believes that when students translate English into English, they focus on accuracy and try to find differences between the two languages, helping to avoid negative transfer. The use of L1 in foreign language classrooms has been debated for many years. In the EFL classroom, there has been much debate over the use of L1, whether it hinders or promotes second language learning. Using the benefits of L1 in EFL classes, students can see the difference between L1 and L2. It will never give them any chance to forbid students from using MT to find a comparison between L1 and L2. In addition, avoiding the use of L1 is a barrier to learners' second language security.

Proponents of English-only believe that using L1 in class does not fit the SLA theory, and SLA theory advocates the modification of second-language input and negotiation as a learning tool (Polio, 1994). Negotiation of meaning and trial-and-error often result in what is known as "interlanguage," a mixture of L1 and L2 is 5used to communicate and establish the correct L2 communication (Weschler, 1997). Recently, some scholars and teachers have begun to advocate more bilingual teaching methods in the L2 classroom. It is even necessary to use L1 in the class (Schweers, 1999). As Zhou (2003) explained, countries like China have successfully experimented bilingual English classes.

The use of L1 has many purposes, such as giving instruction especially at the initial stage to make sure that everyone fully understands what to do (Atkinson 1987; Cole 1998; Machaal 2012; Tang 2002), interpretation of meanings of words (Jingxia 2010; Morahan 2010; Tang 2002) explaining the complex idea of translating from L1 to L2 (Nadzrah \& Kemboja Ismail 2009) and explaining complex grammatical points (Tang, 2002). Regarding students' perceptions of L1 use in L2 classrooms, A1 Sharaeai (2014) examined the reasons and perceptions of learners using their native language in L2 classrooms. The study analyzed the students' perception of the different issues related to the use of the first language. The results showed that students used their L1 for several reasons. The number of first languages is also different such as their language backgrounds, age, and their English language proficiency level. 
This study was conducted to answer the following research questions:

- What factors contribute to the use of Persian in Iranian EFL classrooms?

- What are the teachers' and students' perceptions toward using L1 in EFL classrooms?

\section{METHOD}

\subsection{Research Design}

Regarding the research method, the researchers followed a mixed-methods approach which included student surveys, interviews, focus group discussions, and class observations. All methods are given equally important contributions in research. To design quantitative data, researchers used the Likert scale to collect and analyze numerical data. However, the items within the Likert scale were Strongly Agree, Agree, Neutral, Disagree and Strongly Disagree.

\subsection{Participants}

The participants in this study were 72 students (41 boys and 31 girls) studying at secondary level. They ranged between 14 to 18 years of age. They were studying at public schools in Shiraz, Iran. Among them 12 students were randomly selected to participate in the interview. Thirteen English teachers were also selected to take part in the interview.

\subsection{Instruments}

Researchers collected data through interviews with students and teachers, and provided students with questionnaires and observed the classes. Classroom observation is a quantitative measure of classroom behavior. After observing the course, the researchers asked the teachers' perceptions of using L1 in English classes.

\subsubsection{Teachers' Interview}

The researchers interviewed 13 teachers. The interview time was about 30 minutes. These questions were intended to get a clear idea from the teachers regarding the use of L1 in a foreign language class. Interview questions were prepared to understand the reasons and the necessity of using Persian in English classes. They were asked if they only used English or Persian in English classes. Teachers were not obliged to provide any information.

\subsubsection{Students' Questionnaire}

The questionnaire designed for students included eight closed-ended questions and one open-ended question. There were options for closed-ended questions, depending on the type of question. On the other hand, open-ended questions did not have any option to select, so participants could choose to comment. The open-ended question was a concluding one, and the researchers asked for their ideas about the use of Persian in the class. All participants were made aware of how to complete the questionnaire. They were ensured about the confidentiality of their answers.

\subsubsection{Students' Interview}

Researchers asked students six questions to understand their perceptions of using Persian in English classes. Twelve students participated in the discussion. Researchers established rapport with the students and provided a good environment for them through friendly presentations. Researchers spent approximately 35 to 40 minutes with the students on the interview. The researchers asked for permission from the school before interviewing the students.

\subsubsection{Classroom Observation}

The researchers visited three secondary schools in Shiraz and conducted a 180-minute sample survey from five classes. The observation checklist was used only to understand the general idea of English courses in secondary schools in Iran. While observing the classroom, the researchers tried to record the views that mainly dealt with certain materials. In the checklist, the researchers included some specific information such as class content, skills emphasized by the teachers, materials, the amount of time Persian is spoken in the classrooms, teacher-student interaction, seating arrangements, teaching methods and strategies, and so forth. 


\section{Data Analyses}

\subsection{The Analysis of Teachers' Interview}

In order to analyze teacher interviews, the researchers asked teachers five questions. Almost ten teachers believed that there is no need to use Persian in EFL classes. According to them, excessive use of L1 limits students' awareness of TL. They said that if students always used English in class, they would learn faster. But few teachers expressed their feelings by answering this question. They used $\mathrm{L} 1$ as a classroom tool for signs and images. Using first language is a constructive tool for language learning. They also used Persian in class to explain new words and difficult points in meaning, to clarify the purpose of the text, to check learners' comprehension, and to discuss main ideas after reading. Through the researchers' investigation, nine teachers expressed strong opinions on this issue. Using L1 instead of English in English class can reduce students' experience of learning English. They believed that using L1 to a large extent would be a barrier to TL implementation and would create reliance on MT in EFL classes.

Most teachers said that they only used English in classes, but sometimes they could not completely avoid using English in English class. But few of them thought that L1 could help students learn English better because their students looked more confident when they understood everything. Some teachers strongly opposed the use of L1 in second language classes. They believed that students would never have any advantage when teachers gave students the opportunity to use machine translation in a classroom where FL is the main source of input. So their point of view was that teachers should encourage students to think in English instead of translating it into L1. However, few teachers believed that using MT may increase the chance of learning English quickly. They thought that a lack of understanding can hinder learners' achievement. Therefore, L1 should be used when needed.

Most teachers did not believe that using L1 in a second language class is often a weakness in recognizing teachers' correct teaching. They said that teachers and students can effectively manage classroom interactions by using LI, code-switching, and code alternation. In fact, they believed that getting students to use L1 in class is a humanistic approach which provides them with a chance to say what they wanted. Few teachers said that they always tried to separate the L1 and L2 languages in the classroom, but students always tried to relate the two languages. L1 always came to their minds. In the end, few teachers considered it useful to use L1 in class. They wanted to create an atmosphere of learning a new language with their students. Few teachers agreed that L1 should be applicable when summarizing any material. Few teachers believed that MT can be a useful tool for students to relax because their lack of language skills might cause anxiety among FL students.

\subsection{Analysis of Students' Responses}

Eighty three percent of students believed that Persian should not be used in their English classes. They had a negative attitude toward using L1 in English classes. In addition, they believed that using Persian in the classrooms did not encourage the students to learn English. Eighty three percent of students did not agree that the use of Persian would motivate them to learn English better. However, a large number of English teaching experts believe that too much use of L1 may deprive learners from valuable input in the target language. According to Harmer (2001), excessive use of L1 limits students' awareness of TL. Therefore, teachers should encourage students to think in English instead of translating it into L1. Basically, Iranians have no opportunity to use English outside the classroom, so English can only be learned and taught in the classroom. Twenty two percent of students believed that using Persian in class can help them to learn English better. According to Cole (1998), teachers can use L1 when it is really needed and helpful. Teachers can create a safe and motivating environment for language learning. In Iran, most teachers and students are using L1 without knowing that $\mathrm{L} 1$ can be a useful tool.

Eighty six percent of students believed that using Persian in the classroom prevents them from learning English. According to Harmer (2001), excessive use of L1 limits students' awareness of TL. In addition, the use of L1 will be a barrier to TL in the second language learning class. If learners do not rely on the use of L1, language acquisition will occur. The frequent use of MT in foreign language classrooms may create dependency, which may be a barrier to learning TL in a proper way. It is quite 
clear that $86 \%$ of students think over-use of Persian is the main reason for the decrease in in students' proficiency. However, first language can be used as a tool in second language classes to lower affective filters.

Seventy nine percent of the students believed that using Persian in the classroom could help them learn English better. When students use TL in a foreign language class, their oral performance develops. Sharma (2006) maintains that TL is used only in class because when students are engaged in learning English, they learn faster. Students sometimes use code-switching. In order to avoid a boring class, the teacher can carefully use L1. In fact, having students use L1 in class is a humanistic approach that gives them a chance to say what they want.

Sixty two percent of the students disagreed with the idea that they would learn English grammar better when it explained in Persian. The frequent use of MT in foreign language classrooms may create dependency, which may be a barrier to learning TL in a proper way. Therefore, if learners do not depend on L1, language acquisition will occur. This finding is very similar to that of Atkinson (1987), where teachers should use English whenever possible and Persian if necessary. For English learners, grammar is always a question that requires a deeper level of understanding than Persian. In order to make the grammatical structures more easily, careful use of Persian becomes crucial. Without the help of L1, new grammatical items and vocabulary are not entirely clear to students.

Eighty percent of the students disagreed with the idea that using Persian in the class would motivate them to participate more in class activities. This finding is very similar to Krashen's theory. According to Krashen (1985), TL acquisition depends on exposure to that language. The more learners are exposed to a language, the better they will acquire it. In addition, Howat (1984) points out that FL should be done entirely in EFL classrooms and translation between MT and foreign languages should be limited. Norman (2008) points out that students often do not respond, do not pay attention and do not want to speak in class. When MT is not in the learning environment, students feel uncomfortable, nervous and frustrated. It is hard for every student to catch up with the English course. Language is a burden on them, and they have little interest in the curriculum simply because of the language of the class.

Teachers do code-switching for some specific reasons which are accepted by researchers. Students are not always familiar with new concepts of vocabulary and terminology. Here, the use of MT might become helpful. Thirty percent of student agreed with the idea that teachers should use L1 to explain difficult concepts, and $42 \%$ of them stated that if the teacher explains the difficult concepts in Persian, they will understand better. Fifty eight percent pf students, however, disagreed with the idea that teachers should use Persian to explain difficult concepts because using first language to a large extent will be a barrier to TL learning. Therefore, teachers should encourage students to think in English instead of translating it into L1.

The Lion's share of the participants (75\%) believed that their teachers should not use L1 to clarify the task instructions. Twenty two percent, however, stated that only using English in class can make the class less pleasant and more monotonous. As we know, MT always helps to understand any foreign language. Therefore, code-switching is an outstanding strategy for English learning and teaching. Thus, classroom management owes much to teachers' cautious use of code-switching.

\subsection{Analysis of Students' Interview}

The researchers interviewed 13 students from two different secondary schools. The students said that if their teachers use Persian for example, they will understand better when explaining any difficult meanings or examples. They mentioned that it is easier for them to remember the meaning of difficult words if their teacher explained the words in Persian. This indicates that L1 helps learners keep new vocabulary items in their minds. Few students recommended using MT in the classroom.

Almost all students said that they would not have any problem if their teacher spoke English in the class. However, few students mentioned that sometimes they find it difficult to find suitable English words to express their questions. They also said that when their teachers started their classes with L1, they felt less stressed. The students were asked what they would do if they did not understand what their teacher is saying in English. Few of them said that they would remain silent in the class. They said that they would ask their classmates to clarify the point for them. 
In addition, some students said that the use of Persian should be limited in English classes. They mentioned that overuse of L1 may prevent TL learning and will create a dependence on MT in EFL classes. But few students objected to the prohibition of the use of L1. They said that there is no need to ban the use of mother tongue. They believed that forbidding the use of L1 would hinder the effective understanding of TL.

A few students believed that using Persian in class would mean that it can play a supporting and facilitating role, but not that it is the main language of communication. In addition, by allowing teachers to clarify explanations through the use of L1, vocabulary items and confusing grammar points can relieve students' stress and help them perform more accurately when carrying out the tasks assigned by their teacher.

\subsection{Classroom Observations}

Researchers observed five different classes of five teachers. Most teachers used English in class, but they had to use L1 when explaining difficult words. Although few teachers used L1 to explain the words, they also used English as an example. Therefore, students could associate L1 with L2 and could have a clear understanding of the specific meaning. So, the researchers noticed that most teachers used TL when interacting in the classroom. Although researchers observed feedback from their teachers, they observed that they used L2 in their foreign language classes.

In another classroom, a teacher used L1 after explaining the task. She noticed that some students did not understand her instructions. At that time she checked a student's understanding of the instruction. The student used L1 to explain the task. She was careful to avoid using L1. In very few classes, the researchers found that teachers used examples to explain any grammar rules while using Persian. The teacher gave an example in Persian so that students could understand the content clearly. Teachers mainly corrected their mistakes in English and illustrated them in TLs. Few teachers used Persian in EFL classes to clarify the explanation.

When observing the classroom, researchers also noticed that most teachers did not adopt any specific method or even did not adopt any technology. Teachers used specific books authorized by the school, even without using any real material. No teaching aids such as projectors, computers and microphones were used except the whiteboard and the black marker. Therefore, teachers mainly gave feedback in English. Most teachers appreciated students' participation and attention. Few teachers used motivational words, such as very good, excellent, well done, etc. The researchers found these words effective because students seemed motivated after being acclaimed by their teachers. In fact, positive reinforcement enhanced students' learning the TL.

\section{Results}

Through interviews and questionnaires, teachers and students found their acceptance of the important contribution of MT to learning English. After data analysis and class observation, it was found that Persian could be used by high school students in Iran, which is very useful. For learners, L1 can be a helpful tool if teachers effectively use it in class. Teachers often used L1 to explain difficult questions, explain grammar rules, correct mistakes and give instructions. Because of this, L1 saved time and helped students understand the content.

L1 helped teachers and students to establish rapport, and give them a sense of security. Therefore, L1 encouraged students to communicate with teachers. But there must be a balanced use of L1 and L2 in the classroom. If the teacher thinks any task goes beyond the student's ability, a small amount of L1 can be an effective solution to the obstacles. If learners could understand their tasks and guidance, they might feel more confident, which would make them learn better English.

After observing the classroom, the researchers noticed that when students were banned from using MT in class, they were afraid of speaking English in the classroom. It was also found that if the teachers gave L1 instruction, students could better understand and follow the class more easily. On the contrary, if the teacher always used Persian in an EFL classroom, this might be detrimental to students' motivation and it might reduce their interest in learning TL, hence making them more dependent on L1. Another finding of this study was that MT could be used to support students who could not accomplish their tasks alone. If L1 helped students improve their English, teachers could give students access to L1. The proper use of MT and the functional use of L1 can enhance the effectiveness of language acquisition as a teaching tool. 


\section{CONCLUSION}

This study examined the teachers' and students' perceptions toward using Persian in Iranian EFL classes. This was just a preliminary survey of EFL classroom research in secondary schools in Iran. Most teachers agreed that it is important to use Persian in English classes, but they did not know the reason for using it and did not know the do not know the balance between L1 and L2. Many teachers participating in the study believed that the use of L1 in secondary schools in Iran is inevitable. Using L1 wisely in an EFL classroom can actually be more helpful than blocking.

The results showed that the research hypothesis proved to be true. According to the survey results, students showed great interest in class participation in EFL classes using L1. Teachers and students had positive views about using L1 because they agreed that this is good for learning and it provides a better understanding of the course content. The reason for using L1 was that it helped students enhance their confidence. In class, there was a tendency to use L1 in a variety of ways and activities while clarifying meaning, explaining grammatical paradigms, correcting errors and giving instructions. The results of this study can prove that $\mathrm{L} 1 \mathrm{can}$ be a useful tool for second language learning and can bring a positive attitude and sense of security to the EFL learning process in English. In addition, it was also suggested that it is important to avoid L1 as much as possible in order to make maximum use of $\mathrm{L} 2$ whenever possible. The frequent use of $\mathrm{L} 1$ has been criticized. The primary role of L1 is to lower the affective filter by providing scaffolding through the use of L2 and by making the classroom environment easy to understand. Parents of high school students also expect that English will be used by teachers in English class. The results of this study revealed a variety of teaching benefits of Persian in classroom teaching. Examples include expanding L2 interactions, explaining new vocabulary, explaining grammatical rules, understanding the text, correcting mistakes, organizing classrooms, and establishing rapport with students.

L1 can be used as a valuable teaching tool for EFL classrooms as a function of different strategies. Teachers sometimes use code-switching, and this would satisfy students with their learning process. English is the dominant language in teaching and learning milieu in Iran. Secondary schools in Iran should exercise particular caution while teaching English as a compulsory subject. Qualified and welltrained teachers can play an important role in developing English language skills through the proper use of L1. Teachers should provide proper training to ensure they are able to effectively use the powerful basics of MT as an effective tool. Teachers can be native or non-native, learners can be beginners, intermediate or advanced, and use of L1 is permitted or prohibited based on the students' level of knowledge. The use of L1 in EFL classes is inevitable. Using L1 wisely may enhance the acquisition process and encourage learners to focus on the similarities and differences between MT and TL.

\section{REFERENCES}

[1] AlSharaeai,W.A.A.(2012).Students' perspectives ontheuseofL1inEnglishclassrooms. Digital Repository@ IowaStateUniversity. Retrieved from http://lib.dr.iastate.edu/cgi/viewcontent.cgi? article=3905\&context=etd

[2] Atkinson, D. (1987). The mother tongue in the classroom: A neglected resource?. ELT journal, 41(4), 241247.

[3] Brown, H. (2000). Principles of language learning and teaching (4thed.).Whiteplains, New York: Longman.

[4] Brutt-Griffler, J. (1998). Conceptual questions in English as a world language: Taking up an issue. World Englishes, 17(3), 381-392.

[5] Canagarajah, A. S. (1999). Resisting linguistic imperialism in English teaching. Oxford University Press.

[6] Cole, S. (1998). The use of L1 in communicative English classrooms. LANGUAGE TEACHER-KYOTOJALT-, 22, 11-14.

[7] Cook, V. (2001). Using the first language in the classroom. Canadian modern language review, 57(3), 402-423.

[8] Faltis, C. (1990). New directions in bilingual research design: The study of interactive decision making. Language distribution issues in bilingual schooling, 45-57.

[9] Graddol, D. (1997). The future of English?: A guide to forecasting the popularity of the English language in the 21 st century. British Council.

[10] Harmer,J. (2001).The practice of English language teaching (3rded.).United Kingdom: Pearson

[11] Howatt, A. (1984).A history of English language teaching. Oxford: Oxford University Press. 
[12] Jingxia, L. (2010). Teachers' code-switching to the L1 in EFL classroom. The Open Applied Linguistics Journal, 3(10), 10-23.

[13] Krashen, S. D. (1985). The input hypothesis: Issues and implications. Addison-Wesley Longman Ltd.

[14] Larsen-Freeman, D. (1986). Techniques and principles in language teaching. Oxford: Oxford University Press.

[15] Machaal, B. (2012). The use of Arabic in English classes: A teaching support or a learning hindrance. Arab World English Journal, 3(2), 194-232.

[16] Mahmoud, A. (2006). Translation and Foreign Language Reading Comprehension: A Neglected Didactic Procedure. In English Teaching Forum (Vol. 44, No. 4, p. 28). US Department of State. Bureau of Educational and Cultural Affairs, Office of English Language Programs, SA-5, 2200 C Street NW 4th Floor, Washington, DC 20037.

[17] Meyer, H. (2008). The pedagogical implications of L1 use in the L2 classroom. Maebashi Kyoai Gakuen College Ronsyu, 8, 147-159.

[18] Morahan,M.(2010).The use of students' first language (L1) in the second language (L2) classroom. Retrieved July 20.

[19] Nadzrah A. B., \&Kemboja, I. (2009). Using blogs to encourage ESL students to write constructively in English. AJTLHE: ASEAN Journal of Teaching andLearninginHigherEducation, 1(1),45-57.

[20] Norman, J. (2008). Benefits and drawbacks to L1 use in the L2 classroom. In JALT2007 Conference Proceedings. Tokyo: JALT.

[21] Polio, C. (1994). Comments on Elsa Roberts Auerbach's "Reexamining English Only in the ESL Classroom": A Reader Reacts.... TESOL Quarterly, 28(1), 153-157.

[22] Schweers, C. W. (1999). Using L1 in the L2 classroom. English teaching forum, 37(2), 6-9.

[23] Sharma, K. (2006). Mother tongue use in English classroom. Journal of NELTA, 11(1-2), 80-87.

[24] Tang, J. (2002, January). Using L1 in the English classroom. English Teaching Forum, 40(1), 36-43.

[25] Weschler, R. (1997). Uses of Japanese in the English Classroom: Introducing the Functional-Translation Method. Kyoritsu Women's University Department of International Studies Journal, 12, 87-110.

[26] Zhou, J. (2003). New wine in an old bottle: Innovative EFL classrooms in China. IATEFL Issues, 172, 5-6.

\section{AUTHOR'S BIOGRAPHY}

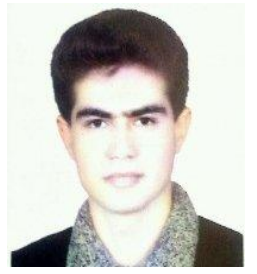

Ali Taghinezhad is a university lecturer at the University of Medical Sciences, Fasa, Iran. He has published several articles in the field of Second Language Acquisition. His areas of interest include language testing, second language learning issues, psycho-linguistics, and educational psychology.

Mehdi Dastpak is presently a faculty member of the University of Medical Sciences. He is also a translator for Nokia Company. He started teaching English at different universities in2004 and has taught English to the students of English, Medicine, and Nursing. His areas of interest include Teaching English, Education, Testing, and Medicine.

Fatemeh Behjat is an assistant professor in TEFL and a faculty member at Islamic Azad University, Abadeh Branch. She has also a 14-year experience in teaching English at Islamic Azad University, Shiraz Branch, The Iran Language Institute, and the Zand Institute of Higher Education. She has so far published papers in local and international high quality journals and presented papers at international conferences at home and abroad. Her area of interests is language learning and teaching.

Citation: Fatemeh Behjat, Mehdi Dastpak, Ali Taghinezhad. "Examining the Factors Influencing the Use of Mother Tongue in Iranian EFL Context: A Mixed-Methods Approach" International Journal on Studies in English Language and Literature (IJSELL), vol 6, no. 3, 2018, pp. 40-49. doi:http://dx.doi.org/10.20431/23473134.0603006.

Copyright: (C) 2018 Authors. This is an open-access article distributed under the terms of the Creative Commons Attribution License, which permits unrestricted use, distribution, and reproduction in any medium, provided the original author and source are credited. 